$A L .2 .2007 .20 t$

C. $\partial$

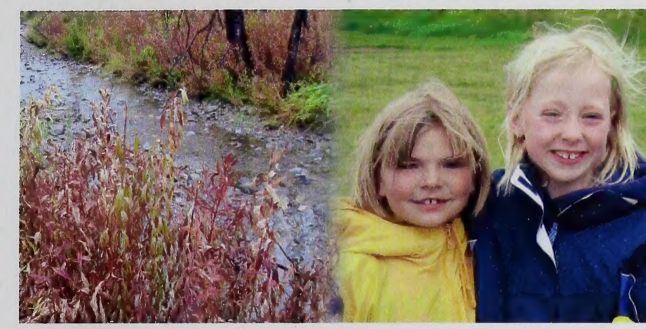

Southern Alberta Landscapes

MEETING THE CHALLENGES AHEAD

Export Coefficients for Total

Phosphorus, Total Nitrogen

and Total Suspended Solids

in the Southern Alberta

\title{
Region
}

\section{A Review of Literature}

Prepared for

Alberta Environment

By Yetunde Jeje 


\section{Southern Alberta Landscapes: \\ Meeting the Challenges Ahead}

\section{Export Coefficients for Total}

Phosphorus, Total Nitrogen and

Total Suspended Solids in the

\section{Southern Alberta Region}

\section{A Review of Literature}

Prepared for

Alberta Environment

By Yetunde Jeje 
Southern Alberta Landscapes: Meeting the Challenges Ahead

\section{Export Coefficients for Total}

Phosphorus, Total Nitrogen and

Total Suspended Solids in the Southern Alberta Region

A Review of Literature 
Digitized by the Internet Archive in 2016

https://archive.org/details/exportcoefficien00jeje_0 
Pub. No. T-863

ISBN: 0-7785-4617-9 (Print version)

ISBN: 0-7785-4618-7 (Online version)

Website: www.gov.ab.ca/env/

Disclaimer: The contents of this document have been prepared with funds from Alberta Environment but do not necessarily reflect the Ministry's views or policies. Any mention of trade names or commercial products does not constitute an endorsement or recommendation for use.

Any comments, questions or suggestions on the content of this document may be directed to:

Regional Environmental Management

Alberta Environment

3rd Floor, Deerfoot Square

2938 - 11 Street N. E.

Calgary, Alberta T2E 7L7

Ph: (403) 297-7602

Fx: (403) 297-6069

Additional print copies of this document are available from:

Information Centre

Alberta Environment

Main Floor, Oxbridge Place

9820-106 Street

Edmonton, Alberta T5K 2J6

$\mathrm{Ph}:$ (780) $427-2700$

Fx: (780) 422-4086

Outside of Edmonton dial 310-0000 for toll-free connection

Email: env.infocent@gov.ab.ca

Copyright in this publication, regardless of format, belongs to Her Majesty the Queen in right of the Province of Alberta. Reproduction of this publication, in whole or in part, regardless of purpose, requires the prior written permission of Alberta Environment.

(C) Her Majesty the Queen in right of the Province of Alberta, 2006. 


\section{CONTENTS}

1.Introduction

1.1. Background

1.2 Objectives

2. Approach

2.1 Literature Review Methods and Sources

2.1.1. Peer Reviewed Publications

2.1.2. Review of Gray Literature

3. Findings

3.1. Available literature on export coefficients

3.1.1. Natural Eco-Regions

3.1.2. Forest or Native and Agricultural Categories

3.1.2.1. Forest or Native Category

3.1.2.2. Agriculture

3.1.3. Non - Native Land Use Categories

3.1.4. Other Considerations

4. Recommendations and Conclusion

4.1. Recommendations

4.2. Conclusion

5. References 


\section{Introduction}

\subsection{Background}

Non-point source pollution generally results from precipitation, land runoff, infiltration, drainage, seepage, hydrologic modification, or atmospheric deposition. Runoff from rainfall and snowmelt pick up and transport natural pollutants arising from human activity, and ultimately deposit them into lentic and lotic systems, wetlands, coastal waters, and ground water (USEPA 2002). As human activities continue to alter the global nutrient cycle, the ability to predict the impact of increased nitrogen, phosphorus and suspended sediment loading to freshwater systems is becoming increasingly important. (Saunders \& Kalff 2001).

Soil erosion, runoff and sediment transport are natural processes. Man and his activities on the land have accelerated the rate of these natural processes. Land characteristics such as soil type, surficial geology, slope and drainage are just as important as land use in determining the extent of soil losses to streams (SwitzerHowse \& Coote 1984). Suspended solids are important for both aesthetic and chemical reasons because they can detract from water clarity and serve to bind and transport phosphorus, heavy metals, pesticides and other toxic compounds.

The use of generalized ecosystem models for predictive research for freshwater and grassland ecosystems are well documented (Park et al. 1979; Parton et al. 1987, 1988). Natural systems possess inherent heterogeneity, and research that is more recent has emphasized the need for general ecological models that can be reparameterized and applied to different ecosystems for distributed, or spatially explicit, simulation (Costanza et al.1990; Band et al.1991 and, Costanza and Maxwell 1991). Although models that incorporate hydrology and water quality have been developed, they are not applicable throughout Canada, especially in the Prairies, due to gaps in knowledge of cold region hydrology and the need for integrating water quality modeling (Chambers et al. 2002). Research is currently underway to characterize prairie hydrology for water quality modeling. It is against this background that the Southern Region of Alberta Environment is developing the ALCES model as a robust tool to manage anthropogenic effects and use the regions natural resources sustainably. The identification of the contributing effects of the various land uses and natural resources on the export of phosphorus, nitrogen and suspended solids is central to determining some of the key issues to be addressed in the regional strategy for Southern Alberta in order to ensure sustainable development over the next 50 years. 


\subsection{Objectives}

The objectives of the literature review were to:

- Identify and summarize literature that provide quantitative information on Total Nitrogen (TN), Total Phosphorus (TP) and Total Suspended Solids (TSS) export coefficients in the Southern Alberta region,

- Identify and summarize literature that provide quantitative information on TN, TP and TSS export coefficients in the following landscape cover categories provided by Alberta Environment, Calgary: Native Prairie (9) classes, Agriculture (6) classes, Forest Area (7) classes and Miscellaneous (4) classes for input in the ALCES computer simulation model currently under development.

- Prepare a report that presents a descriptive inventory and analysis of literature including a list of all relevant literature reviewed and abstracts of selected literature appropriately categorized, and provide a discussion of data generated.

- Identify and summarize literature that provides quantitative information on TN, TP and TSS export coefficients for Non-native Land Use categories in the Southern Alberta region. This assignment was included on Thursday April 28, 2003.

\section{Approach}

This section provides information on the methods used to review the literature and the categories selected to organise the findings. Journal publications and relevant gray literature (government reports and documents published outside of the traditional peer review and publication process) were reviewed.

\subsection{Literature Review Methods and Sources}

Various methods used to search both published literature and gray literature are described in the following sections

\subsubsection{Peer Reviewed Publications}

Literature searches were conducted in the following databases 
University of Calgary Library Electronic Resources

1. Key Environmental Science Indexes and Abstracts

- Agricola

- Applied Science and Technology 1983-present

- Biological Abstracts 1980-Present

- Environment Abstracts

- EPA Environmental Publications

- Pollution Abstracts 1981-Present

2. Key Biology Indexes and Abstracts

- Biological Abstracts 1980-Present

- LexisNexis Environmental

- Web of Science

The searches used the following keywords individually or in combinations: nutrients, phosphorus, nitrogen, suspended solids, total, export coefficients, runoff, transport, loading, prairie, grassland, watersheds, parkland, foothills, rocky mountain, native vegetation, agriculture, urban, industrial, Alberta, Canada and North America

The search produced hundreds of references and a manual review was conducted to identify relevant references for the purpose of this report.

\subsubsection{Review of Gray Literature}

Literature searches of "gray literature" of government (federal, state, and provincial sectors) were conducted on the Alberta Government Library and the internet. Searches focused on the following organizations:

- Environment Canada,

- Alberta Environment

- Alberta Agriculture, Food and Rural Development

- Agriculture and Agri-Food Canada

- Fisheries and Oceans Canada

- Canadian Water and Waste Association

- National Research Council of Canada

- Food and Agriculture Organization of the United Nations

- Canadian Council of Ministers of the Environment

- United States Environmental Protection Agency and

- United States National Technical Information Service (NTIS)

Once again, a large number of records were obtained through these search strategies and these were manually reviewed and sorted according to relevance. 
Nitrogen and Phosphorus are essential components of a healthy ecosystem and occur naturally in the environment (Wetzel 2001). Most human activities can contribute new sources of these nutrients to aquatic systems, increase the rate of loss of nutrients from the landscape, degrade water quality and contribute to eutrophication. Nutrient loading from watershed processes occurs through transport of nutrients from land to water. This is generally more difficult to quantify than direct effluent discharge because it is usually more diffuse, variable, and intermittent. While predominant impacts have occurred in aquatic ecosystems and caused water use impairments, symptoms of negative effects on forest ecosystems have also been observed (Chambers et al. 2002).

Nutrient load export in surface runoff is dependent on soil type, vegetation cover, precipitation and the type of land use activities. There is concern about the increasing contribution of agricultural operations to nutrient enrichment of water bodies in Alberta (Howard et al. 1999). Primary agricultural non-point source pollutants are nutrients, sediment, animal wastes, and pesticides. Nitrogen $(N)$ and Phosphorus $(P)$ are the two major nutrients in surface runoff that can degrade water quality and contribute to eutrophication. Nitrogen occurs naturally in soils, although often in insufficient quantities, thereby requiring addition from fertilizers and manure in order to meet crop production needs. Phosphorus, however, is believed to control the level of primary production in western Canadian lakes. Many of the lentic and lotic systems in Alberta are naturally eutrophic. They are therefore extremely sensitive to further phosphorus enrichment. (Howard et al. 1999).

Nutrient or sediment loads from watershed processes for specific land uses can be calculated from export coefficients. Export coefficients represent the quantity of nutrients or sediment generated per unit area per unit time $(\mathrm{kg} / \mathrm{ha} / \mathrm{yr})$. Use of export coefficients is based on the assumption that a given land use activity will yield a specific quantity of nutrients/sediments to a downstream waterbody (McFarland \& Hauck 2001).

There is a wide range of export coefficients for total phosphorus and total nitrogen in the literature for any given land use in the United States (Oberts 1983 USEPA 1976, 2001; Barker et al. 1989; Reckhow et al. 1980 and, EPA 1992). There is however, a paucity of similar information in Canada particularly in the Prairies. Therefore, this literature review includes export coefficients from the classic paper of Reckhow et al. 1980 mainly for comparative purposes, in addition to other more selective records from the United States. The publication by Riemersma et al. 2002 documenting phosphorus sources and sinks in watersheds provides significant information for Alberta. Export coefficients were also derived from data extracted and transformed from Sosiak 2000 (Mosquito Creek and Little Bow River), Ontkean et al. 2000 (Crowfoot Creek), Wilhelm \& Schindler 1999 (Snowflake Lake) and Silva \& Davies 1997 (Oldman River). Joanne Little, Alberta Agriculture, Food and Rural Development, Lethbridge, and Anne-Marie Anderson, Alberta Environment, Edmonton, also provided data for inclusion. 


\subsection{Available literature on export coefficients for phosphorus, nitrogen and total suspended solids}

An initial search was conducted using the various search engines with keywords for each of the land use groupings provided for ALCES by Alberta Environment, Calgary (Table 1). No export coefficients were found for any of these classes. A map showing natural ecoregions for Alberta was obtained from the Alberta Natural Heritage Information Centre (ANIC) website:

http://www/cd.gov.ab.ca/preserving/parks/anhic/natura regions map.asp

It was adopted for grouping of the cover types in Table 1. Four natural eco-regions were identified in the southern Alberta region. These were Rocky Mountain, Foothills, Parkland, and Grassland (Table 2). Watersheds were also included in this table in order to accommodate data provided by Ellis \& Stanford, 2000 from Montana. Forest and Agriculture classes were classified under Native and Agricultural uses (Table 3).

Table 1. Cover Types to be included in the ALCES model for Southern Alberta Landscapes: Meeting the Challenges Ahead (Provided by Alberta Environment, Calgary)

\begin{tabular}{|c|c|}
\hline Catecorv & Classes \\
\hline \multicolumn{2}{|l|}{ Native Prairie } \\
\hline & Needle and Thread Dry Mixed Grass (Blue Grama) \\
\hline & Northern Wheat Dry Mixed Grass (June grass) \\
\hline & Needle and Thread Sand Grass \\
\hline & Mixed Grass-Wheat Grass, Needle and Thread Grass \\
\hline & Fescue Grassland - Foothills and Northern Fescue, Rough fescue, Idaho \\
\hline & Fescue Parkland - Foothills Parkland and Montane - Rough Fescue - \\
\hline & Prairie Shrubs \\
\hline & Badlands and line breaks (valley sides and coulees) \\
\hline & Riparian Cottonwood Complexes (Lentic and Lotic related) \\
\hline \multicolumn{2}{|l|}{ Aariculture } \\
\hline & Cereal \\
\hline & Oilseeds \\
\hline & Lequmes \\
\hline & Specialty \\
\hline & Forage \\
\hline & Tame Pasture \\
\hline \multicolumn{2}{|l|}{ Forest } \\
\hline & Hardwood \\
\hline & Mixed wood \\
\hline & Black Spruce \\
\hline & Douglas Fir \\
\hline & Pine \\
\hline & Prairie treed \\
\hline \multicolumn{2}{|l|}{ Other } \\
\hline & Alpine \\
\hline & Rock/lce \\
\hline & Forest Shrub \\
\hline & Forb \\
\hline
\end{tabular}




\subsubsection{NATURAL ECO-REGIONS}

Much of Southern Alberta was covered with grassland prior to the advent of mechanized farming. An increase in human land use has significantly decreased the area of grassland in the region. There is limited information on export coefficients for natural eco-regions in the southern Alberta region (Table 2). This is because few areas have remained unaffected by the effects of livestock and fertilizer additions to farmland (Riemersma et al. 2002). This has necessitated the data extraction, transformation, and derivation of export coefficients from publications with sufficient information to do so. Such coefficients were derived for Alpine, Foothills Parkland and Dry mixed grass (Wilhelm \& Schindler 1999; Sosiak, 2000; Ontkean et al. 2000 and Silva \& Davies 1997 respectively). Areas of sub-drainage basins were obtained from the Canadian Water Survey database and used for the calculations. Such calculated export coefficient values serve only as estimates as they are based on limited information.

Golder Associates, 1999 reported export coefficients for TP and TN for high and low runoff in a small drainage basin (Red Deer tributary) from the Parkland eco-region. These values are probably from an agricultural basin as they are considerably higher than other values in this category. Values for TP and TN export coefficients were much lower during the low runoff season (TP $0.07 \mathrm{~kg} / \mathrm{ha} / \mathrm{yr}$ : TN $0.10-0.60 \mathrm{~kg} / \mathrm{ha} / \mathrm{yr}$ ) than in the higher runoff season (TP 0.26-3.37 kg/ha/yr; TN 2.00-14.00 kg/ha/yr). Higher loads corresponding to heavy rain events have been previously recorded (Jensen et al. 1998, Xue et al. 1998).

Export coefficients were not found in this search for Montane, Upper and Lower Foothills, Peace River Parkland, Dry Mixed Grass and Northern Fescue. Export coefficients for TN for various watersheds in Montana ranged between $0.18 \mathrm{~kg} / \mathrm{ha} / \mathrm{yr}$ and $1.27 \mathrm{~kg} / \mathrm{ha} / \mathrm{yr}$. Northern Montana has climatic conditions and eco-regions similar to that of southern Alberta.

No reports were available for export coefficients of total suspended solids. Sosiak 2000 was the only record that was suitable for data extraction and transformation. Values varied between $18.07 \mathrm{~kg} / \mathrm{ha} / \mathrm{yr}$ and $42.90 \mathrm{~kg} / \mathrm{ha} / \mathrm{yr}$ in Foothills Parkland and 24.02 $\mathrm{kg} / \mathrm{ha} / \mathrm{yr}$ and $100.99 \mathrm{~kg} / \mathrm{ha} / \mathrm{yr}$ in the Mixed Grass eco-region.

\subsubsection{FOREST OR NATIVE AND AGRICULTURAL CATEGORIES}

\subsubsection{FOREST OR NATIVE CATEGORY}

Nutrient losses in surface water runoff arising from forest management practices have been determined for few sites in Canada. The variations in climate, topography, and diversity of vegetation across Canada have made it difficult to assess the effect of forest management practices on water quality and quantity (Chambers et al. 2002).

Forested areas discharge less phosphorus than agricultural or urbanized land (Cooke and Prepas 1998). Manipulation of forest watersheds can drastically affect the physical characteristics of water in lentic and lotic systems, with sediment loads being generally high. Clear cutting has been demonstrated to increase the concentration of dissolved nutrients in surface runoffs. Forest removal affects nutrient leaching from forests by 
eliminating nutrient uptake by trees for a period of time ( Douglas St.Onge et al. 1999, Devito et al. 2000 ).

There have been several studies on localized impacts from agricultural activities on phosphorus and nitrogen loadings of surface waters on the Prairies (Mitchell 1992; Anderson et al. 1995; Green 1996; Sosiak and Trew 1996; Anderson et al. 1998a, 1998b, 1998c; Cooke and Prepas 1998; Sosiak 2000, and Ontkean et al. 2000). Few studies provide information on export coefficients in the southern Alberta region (Table 3). Attempt was made to search for relevant literature with similarity to Alberta conditions. Selective information from the United States was also tabulated for comparative purposes. Land use categories were grouped as Forest or Native vegetation and Agriculture. Each category was further sub-divided as determined from literature sourced.

TP values from the Forest and Native vegetation were variable and ranged between $0.05 \mathrm{~kg} / \mathrm{ha} / \mathrm{yr}$ and $0.20 \mathrm{~kg} / \mathrm{ha} / \mathrm{yr}$. TP export coefficients of $0.07 \mathrm{~kg} / \mathrm{ha} / \mathrm{yr}$ to 0.10 $\mathrm{kg} / \mathrm{ha} / \mathrm{yr}$ have been recorded for other areas in the United States (see Table 3), (Oberts et al. 1989, MDEQ 2001) and $0.20 \mathrm{~kg} / \mathrm{ha} / \mathrm{yr}$ (Beaulac and Reckhow 1982). The use of a wide range of documented values makes selection of export coefficients for modeling more statistically enabling and error margins lower.

There was less information available in the literature for export coefficients for TN (Table 3). Values ranged between $2.33 \mathrm{~kg} / \mathrm{ha} / \mathrm{yr}$ and $2.50 \mathrm{~kg} / \mathrm{ha} / \mathrm{yr}$ for locations in the United States. Nitrogen is considered as the nutrient that most often limits net primary production in forest ecosystems, particularly those in temperate and boreal regions (Vitousek and Howarth 1991). Fertilization studies involving single $\mathrm{N}$ applications have confirmed that $\mathrm{N}$ is the major limiting element for tree growth in many Canadian forest ecosystems (Weetman et al.. 1987; Morrison and Foster 1990), although not all forests in Canada are $\mathrm{N}$ limited.

All three agents of erosion - wind, water, and tillage (PFRA 2000), affect much of the Prairies. Agricultural development on the Prairies has resulted in widespread land clearing and drainage, soil erosion, water withdrawals, livestock concentration areas, land application of manure and inorganic fertilizer and the use of pesticides. These developments have had adverse effect on water quality.

Only two records of export coefficients for total suspended solids were retrieved for Forest and Native vegetation (Table 3). Similar values were cited by USEPA 1976 $(250.00 \mathrm{~kg} / \mathrm{ha} / \mathrm{yr})$ and Reckhow et al. $1980(253.00 \mathrm{~kg} / \mathrm{ha} / \mathrm{yr})$ for locations in the United States. Surface runoff from grass or non-cultivated soils carries little sediment and is therefore generally dominated by dissolved $\mathrm{P}$. 


\section{Table 2 : Export Coefficients for Natural Eco-region Categories}

ategory \& Subdivisior Export Coefficients kg/haly

References Notes

\begin{tabular}{|c|c|c|c|c|}
\hline NATURAL ECOREGIONS & TP & TN & TSS & \\
\hline \multicolumn{5}{|l|}{ Rocky Mountain } \\
\hline Alpine & $0.03-0.15$ & & & Snowflake lake, Banff- Wilhelm \&Schindler 1999 (1) \\
\hline Subalpine & $0.10-0.30$ & $1.75-3.75$ & & Bondelid et al. 2001, USEPA contract report \\
\hline \multicolumn{5}{|l|}{ Montane } \\
\hline & & & & \\
\hline \multicolumn{5}{|l|}{ Foothills } \\
\hline \multicolumn{5}{|l|}{ Upper Foothills } \\
\hline \multicolumn{5}{|l|}{ Lower Foothills } \\
\hline \multirow{2}{*}{\multicolumn{5}{|c|}{ Parkland }} \\
\hline & & & & \\
\hline Foothills Parkland & $0.03-0.08$ & $0.20-0.82$ & $18.07-42.90$ & Sosiak 2000, Mosquito Creek \& Little Bow River (2) \\
\hline \multicolumn{5}{|c|}{\begin{tabular}{|l|l|} 
Peace River Parkland & \\
\end{tabular}} \\
\hline & & & & \\
\hline \multicolumn{5}{|l|}{ Grassland } \\
\hline \multicolumn{5}{|l|}{ Dry Mixed grass } \\
\hline Foothills Fescue & $0.01-0.21$ & $0.05-1.24$ & $24.02-100.99$ & Sosiak 2000, Mosquito Creek \& Little Bow River \\
\hline \multicolumn{5}{|c|}{ 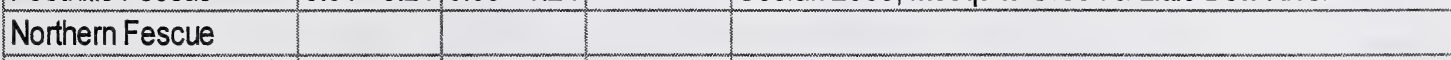 } \\
\hline Mixed Grass (Native Grass) & 0.11 & & & Timmons \& Holt 1977 \\
\hline Mixed Grass & $0.11-0.47$ & $0.05-2.34$ & & Ontkean et al. 2000 , Crowfoot Creek (3) \\
\hline Mixed Grass & $0.12-0.36$ & $0.24-1.58$ & & Silva \& Davies 1997 , Oldman River (4) \\
\hline Mixed Grass & 0.04 & 1.08 & & Silva \& Davies 1997, Oldman River (4) \\
\hline \multicolumn{5}{|l|}{ Watersheds } \\
\hline Ashley Creek & & 1.27 & & Ellis \& Stanford 2000, Montana \\
\hline StillwaterMhitefish & & 0.91 & & Ellis \& Stanford 2000, Montana \\
\hline Main-stem Flathead & & 0.89 & & Ellis \& Stanford 2000, Montana \\
\hline Swan & & 0.58 & & Ellis \& Stanford 2000, Montana \\
\hline Stoner Creek & & 0.18 & & Ellis \& Stanford 2000, Montana \\
\hline Forested Watershed & $0.05-0.22$ & & & Cooke \& Prepas 1998, Baptiste Lake AB \\
\hline Agricultural Watershed & $0.12-0.82$ & & & Cooke \& Prepas 1998, Baptiste Lake AB \\
\hline Wetlands & 0.01 & 0.55 & & The Cadmus Group 1998, Schuylkill River Basin \\
\hline \multirow[t]{2}{*}{ Agricultural Basin } & $0.7 \mathrm{~L}$ & $0.10-0.60$ & & Golder Associates $1999^{*}$.low $(L)$ and high $(H)$ runoff in a small \\
\hline & $0.26-3.37 \mathrm{H}$ & $2.00-14.00$ & & drainage basin located in Red Deer tributary \\
\hline \multicolumn{5}{|c|}{${ }^{*}$ Cited in Manitoba (MLMMI) 2002} \\
\hline \multicolumn{5}{|c|}{ 1,2,3,4 Data extracted and transformed } \\
\hline & & & & \\
\hline & & & & \\
\hline
\end{tabular}




\section{Table 3: Export Coefficients for Native and Agricultural Categories}

\begin{tabular}{|c|c|c|c|c|}
\hline LAND USE & TP & TN & TSS & \\
\hline \multicolumn{5}{|c|}{ Forest / Native Vegetation } \\
\hline Natural vegetation & 0.0085 & 0.44 & & USEPA 2002 \\
\hline Mostly natural & 0.018 & 0.45 & & USEPA 2002 \\
\hline Baptiste & 0.14 & & & Mitchell \& Trew 1992, north of Edmonton \\
\hline Baptiste & $0.05-0.22$ & & & Cooke \& Prepas 1998 \\
\hline Wabamum & 0.09 & & & Mitchell \& Trew 1992, west of Edmonton \\
\hline Aspen Birch & 0.13 & & & Timmons et al. 1997 (in Riemersa et al 2002) \\
\hline Native Prairie & 0.11 & & & Timmons \& Holt $1997^{*}$ \\
\hline Two Creek & 0.12 & & & Munn \& Prepas $1986^{*}$ \\
\hline Saskatchewan & 0.08 & & & Munn \& Prepas. $1986^{*}$ \\
\hline Forest & 0.20 & 2.50 & 250.00 & USEPA 1976; median values \\
\hline ForestWetland & 0.13 & 2.33 & & Dodd et al. 1992, North Carolina \\
\hline OpenWooded/Park & $0.07-0.10$ & & & Oberts et al. 1989, Minnesota \\
\hline Forest & 0.21 & 2.46 & 253.00 & Reckhow et al. 1980 \\
\hline Forest & 0.20 & & & Beaulac \& Reckhow $1982^{* *}$ \\
\hline Forest & $0.05-0.12$ & & & Lassavils \& Berrux 2000, Canada \\
\hline Forest & 0.20 & 2.50 & & Montana DeptEnviron Quality (MDEQ) 2001 \\
\hline Unmanaged Forest & $0.035-0.05$ & & & MDEP 2000 \\
\hline Managed Forest & $0.50-0.75$ & & & MDEP 2000 \\
\hline Forest (Clear cutting) & $0.18-0.60$ & & & Douglas St.Onge et al 1999 , Quebec \\
\hline Forest & 0.30 & & & Carmmermeyer et al 2000, Lake Washington/Sammamish Watershed \\
\hline \multicolumn{5}{|l|}{ Agriculture } \\
\hline \multicolumn{5}{|l|}{ Non Intensive } \\
\hline Range/ Pasture & 0.30 & 5.00 & 400.00 & USEPA 1976 \\
\hline Pasture/Hay & 0.81 & 5.19 & 514.5 & Reckhow et al. 1980 \\
\hline Pasture & 1.00 & & & Lassavils \& Berrux 2000, Canada \\
\hline Pasture & 0.90 & 5.10 & & MDEQ, 2001 \\
\hline Grassland, grazed & $0.20-1.42$ & & & Mitchell \& Hamilton $1982^{\star \star}$, Lake Wabamum \\
\hline Cultivated land & $0.028-0.262$ & & & Anderson et al. 1998, **Haynes Creek, AB \\
\hline Agriculture & 0.99 & 9.80 & & Dodd et al. 1992, North Carolina \\
\hline Agriculture & $0.50-0.70$ & & & Oberts et al. 1989, Minnesota \\
\hline Agriculture & 0.031 & 0.98 & & USEPA 2002 \\
\hline Mostly Agriculture & 0.028 & 0.63 & & USEPA 2002 \\
\hline Wabanum & 0.16 & & & Mitchell \& Trew 1992, west of Edmonton \\
\hline Baptiste & 0.27 & & & Mitchell \& Trew 1992, north of Edmonton \\
\hline Agriculture & 0.40 & & & Meals $1987^{\star}$ \\
\hline
\end{tabular}




\begin{tabular}{|c|c|c|c|c|}
\hline & & & & \\
\hline Intensive & & & & \\
\hline Dairy Farms & 0.10 & & & Meals $1987^{\star}$ \\
\hline Mixed agriculture & 0.99 & 14.90 & & MDEQ 2001 \\
\hline Mixed & 1.10 & & & Olness et al. $1975^{*}$ \\
\hline Mixed agric/urban/cattle & 0.50 & & & Field 1986 \\
\hline Mixed & & & 4900.00 & Van Viet \& Hall 1991, Peace River,Saskatoon; fallow/canola/barley \\
\hline Mixed & & & 1000.00 & Van Vliet \& Hall 1991, Peace River,Saskatoon; fallow/canola/barley/fescu \\
\hline Wheat stubble & 0.40 & 10.00 & & Nicholaichuk \& Read 1978, Swift Current, Saskatchewan \\
\hline Wheat & 2.96 & & & Olness et al. $1975^{*}$, Oaklahoma \\
\hline Wheat & $1.10,7.90$ & $2.00,3.60$ & & Hargrave \& Shaykewich 1991; runoff from sandy loam clay and sand loam \\
\hline Wheat & & & 1440.00 & Larney et al. $1995 \mathrm{~b}$, Southern Alberta \\
\hline Wheat & & & 1900.00 & Pennock \& de Jong 1990, Saskatoon Prairie \\
\hline Wheat-Agriculture & & & $2100-2716$ & Pennock \& de Jong 1987, Saskatoon Prairie \\
\hline Fall fertilized,summerfallow & 2.90 & & & Nicholaichuk \& Read 1978, Swift Current, Saskatchewan \\
\hline Wheat, summerfallow & 1.40 & & & Nicholaichuk \& Read 1978 Swift Current, Saskatchewan \\
\hline Summer fallow & $0.10-0.32$ & $0.13-1.48$ & & Ontkean et al. 2000, Crowfoot Creek(transformed data) \\
\hline Fallow & $5.80,7.30$ & $3.10,6.30$ & & Hargrave \& Shaykewich 1991"; runoff from sandy loam clay and sand loam \\
\hline Cotton (Dryland) & 5.01 & & & Olness et al. $1975^{*}$ \\
\hline La Nonne & 0.50 & & & Mitchell \& Trew 1992, Northwest Alberta \\
\hline Cropland & $0.01-0.63$ & $0.10-2.13$ & & Ontkean et al. 2000, Crowfoot Creek(transformed data) \\
\hline Non row crops & 0.70 & & & Reckhow et al. 1980; alfalfa, wheat, corn \\
\hline Non row crops & 0.80 & 6.80 & & MDEQ 2001 \\
\hline Row crops & 2.20 & 8.20 & & MDEQ 2001 \\
\hline Row crops & 2.00 & & & Beaulac \& Reckhow $1982^{\star \star *}$ \\
\hline Row crops & 2.24 & 9.00 & & MDEP 2000 \\
\hline Corn/Soybean & 2.20 & & & Reckhow et al. 1980; \\
\hline Corn/Soybean & $3.80,9.40$ & $12.30,7.90$ & & Hargrave \& Shaykewich 1991^; runoff from sandy loam clay and sand loam \\
\hline Alfalfa & $0.06,0.33$ & & & Hargrave \& Shaykewich 1991^; runoff from sandy loam clay and sand loam \\
\hline Alfalfa & 2.48 & & & Olness et al 1975, Oaklahoma \\
\hline Rotation Crops & $1.50-3.50$ & & & MDEP 2000 \\
\hline Intensive, arable & $3.00-5.00$ & $1.00-6.00$ & & Frissel 1978, N. Carolina, soybeans, wheat, potatoes \\
\hline Intensive livestock, grazed & 0.20 & $1.0-12.0$ & & Frissel 1978, N. Carolina, grazed bluegrass \\
\hline Flood irrigated farmland & 0.20 & & & Oosterveld \& McMullin 1979, ${ }^{* \star}$ Southern Alberta, Hayes \\
\hline Sprinkler irrigated farmland & 0.30 & & & Oosterveld \& McMullin 1979, **Southern Alberta, Hayes \\
\hline Irrigated Watershed & 1.93 & & & Olness et al 1975, Oaklahoma \\
\hline Dryland Watershed & $0.71-1.23$ & & & Olness et al 1975, Oaklahoma \\
\hline Irrigated land & $0.002-0.048$ & & & Little AFFRD, unpublished, Battersea Drain \\
\hline Cattle Wintering sites & $0.04-0.37$ & & & Anderson et al 1998, Hayes Creek AB \\
\hline Feedlot, manure storage & 255.00 & & & Reckhow et al. 1980 \\
\hline Feedlot & 250.00 & 1000.00 & & USEPA 1976 \\
\hline Feedlot, manure storage & 260.00 & 2900.00 & & MDEQ, 2001 \\
\hline${ }^{*}$ Cited in Mitchell \& Trew 1992 & & & & \\
\hline${ }^{*} \mathrm{C}$ Cited in Riemersma et al 2002 & & & & \\
\hline${ }^{\wedge}$ MLMMII 2002 & & & & \\
\hline
\end{tabular}




\subsubsection{AGRICULTURE}

This class was further subdivided into non-intensive and intensive groupings. Considerably more information was available for this class for Alberta and the Prairies, although there have been very few studies relating specific agricultural management practices and suspended solids as export coefficients (Table 3). Farm practices such as tillage, degree of vegetative cover, crop type and inorganic and, organic fertilizer applications yielded different export coefficients.

\subsubsection{2a. Total Phosphorus and Total Nitrogen Export Coefficients for Non-Intensive Agriculture}

Export coefficients for phosphorus recorded under pasturing conditions ranged between $0.30 \mathrm{~kg} / \mathrm{ha} / \mathrm{yr}$ to $1.00 \mathrm{~kg} / \mathrm{ha} / \mathrm{yr}$. Records for non-intensive agricultural practices were variable. They ranged between $0.028 \mathrm{~kg} / \mathrm{ha} / \mathrm{yr}$ and $0.40 \mathrm{~kg} / \mathrm{ha} / \mathrm{yr}$ for Alberta (Table 2) (Mitchell \& Trew 1992, Anderson et al. 1998). Records for the United States were slightly higher, with a range between $0.50 \mathrm{~kg} / \mathrm{ha} / \mathrm{yr}$ and $0.99 \mathrm{~kg} / \mathrm{ha} / \mathrm{yr}$ being recorded.

Values reported for nitrogen from pasture ranged between $5.00 \mathrm{~kg} / \mathrm{ha} / \mathrm{yr}$ and 5.10 $\mathrm{kg} / \mathrm{ha} / \mathrm{yr}$ (USEPA 1976, MDEQ, 2001). Reckhow et al. 980 reported a TN value of 0.33 $\mathrm{kg} / \mathrm{ha} / \mathrm{yr}$ also from the United States. For general agricultural practice in North Carolina, Oberts et al. 1989 reported a TN export coefficient of $9.8 \mathrm{~kg} / \mathrm{ha} / \mathrm{yr}$.

\subsubsection{2b. Total Phosphorus and Total Nitrogen Export Coefficients for Intensive Agriculture}

Export coefficients were recorded for various intensive agricultural practices (Table 3). Records for intensive agricultural practices were understandably variable due to the different crops planted. There were few reports for Alberta (Ontkean et al. 2000, Osterveld \& McMullin 1979, and, Little, pers comm). No distinct trends could be identified between and within subgroups aside from three subgroups with similar records. Closely similar (two to three) records were obtained within the following sub groupings : Non row crops (0.70 TP kg/ha/yr and $0.80 \mathrm{TP} \mathrm{kg} / \mathrm{ha} / \mathrm{yr}$ ), Row crops (2.00 $\mathrm{TP} \mathrm{kg} / \mathrm{ha} / \mathrm{yr}$ and $2.20 \mathrm{TP} \mathrm{kg} / \mathrm{ha} / \mathrm{yr}$, and, Feedlot manure storage (250.00 TSS kg/ha/yr to $260.00 \mathrm{TSS} \mathrm{kg} / \mathrm{ha} / \mathrm{yr}$ ). Records were from the United States.

The loss of phosphorus in agricultural runoff occurs in sediment-bound and dissolved forms. Sediment phosphorus includes $P$ associated with soil particles and organic material eroded during flow events and constitutes between 60 and 90 percent of $P$ transported in surface runoff from most cultivated land (Sharpley et al.. 1992). Many studies conclude that dissolved phosphorus loss in surface runoff is dependent on the phosphorus content of surface soil. In a review, Sharpley et al. 1996 found that the relationship between surface runoff $P$ and soil $P$ varies with management and is linked to soil $\mathrm{P}$ concentration. The timing of application of fertilizers and manure also play a major role in loss of phosphorus in runoff. Phosphorus in runoff from frozen ground loss may account for significant P loss as noted by Nicholaichuk and Read 1978 and the results of Hargrave and Shaykewich 1991 (Table 3). 
The dissolved form of $P$ arises from its release from soil and plant material. Most dissolved $P$ is immediately available for biological uptake. Sediment $P$ is not as readily available, although it can serve as a long-term source of phosphorus for aquatic biota (Sharpley, 1993; Elkholm, 1994). Leaching of nutrients might be minimal on the prairies of western Canada because potential evaporation and transpiration rates exceed precipitation by a very wide margin (Fairchild et al. 2000).

\subsubsection{2c. Export Coefficients for Total Suspended Solids for Non- Intensive and Intensive Agriculture}

There were far fewer records of export coefficients for total suspended solids in the literature. Larney et al. 1995b reported an export coefficient of $1440.00 \mathrm{~kg} / \mathrm{ha} / \mathrm{yr}$ from southern Alberta. Other reports from the Saskatchewan Prairie recorded an order of magnitude of three to four times values reported for non-intensive agriculture from the United States (Pennock and de Jong 1987, 1990; Van Vliet and Hall 1991). See Table 3.

Much eroded soil never leaves field boundaries but is re-deposited in depressions or behind clumps of vegetation. Up to $80 \%$ of water eroded soil has been found to remain in the field (Novotny and Chesters, 1981, 1989). The key water quality concern related to field runoff is the transport of sediments into surface waters. It is not clear, however, how important sedimentation from field runoff is on the Canadian Prairies (Anderson et al. 1998a; Environment Canada 1990). The sediments and the nutrients or chemicals adsorbed to soil particles can lead to water quality impairment and smothering of some aquatic organisms may occur.

\subsubsection{NON-NATIVE LAND USE CATEGORIES}

Export coefficients for non-native land use categories are presented in Table 4. Few records were found for Alberta. Coefficients for urban land use varied between residential, commercial or recreational and, location.

\subsubsection{Municipal Wastewater Effluents}

Effluent from municipal wastewater treatment plants, industrial effluent, and stormwater are regarded as point sources of pollution. There is considerable information on water quality guidelines and total loading of municipal and industrial wastes to surface water. However, much of the information is presented in the form of percentage values relative to total loading, or recorded as $\mathrm{g} / \mathrm{m}^{2} / \mathrm{yr}, \mathrm{mg} / \mathrm{l}$ or $\mathrm{kg} / \mathrm{d}$. There is comparatively much less information presented as export coefficients from these sources.

Nutrient sources in municipal wastewater include human waste, household cleaning products, and by-products from industries that dispose wastewater to municipal sewer systems. Nitrogen enters domestic wastewater mainly from human waste. Phosphorus sources to municipal wastewater are more varied than nitrogen sources, arising from 
human waste, detergent and general-purpose cleaners, and, commercial and industrial sources.

Chambers et al. 2002 evaluate anthropogenic sources of nitrogen and phosphorus in Canada. Data are provided on sources and total loadings in municipal and industrial effluents. Nutrient losses from agricultural activities to surface and groundwater's were mainly presented as percent of nutrient application in fertilizers and manure. Export coefficients were presented for stormwater runoff for various locations in Canada, which have been incorporated in Table 4. Riemersma et al. 2002 present more region specific information in their review of phosphorus sinks and sources that may affect Alberta's water resources.

In urban areas, snowmelt or stormwater runoff from house roofs, parking lots, and streets discharge into the municipal sewer system. Sewer systems built before the early 1940's disposed of household wastewater by discharge into rivers, lakes or coastal waters. All the major Prairie cities (Edmonton, Calgary, Saskatoon, Regina, and Winnipeg) provide secondary treatment of wastewater. Regina, Saskatoon, Calgary, Toronto and Ottawa also undertake advanced phosphorus removal (tertiary treatment) (Chambers et al. 2002). It was for this reason that documented values for Toronto and surrounding areas were included. 
Table 4: Export Coefficients for Non-Native Land Use Categories
Category 8 Subdivisions
Export Coefficients kg/halyr
References Notes

\begin{tabular}{|c|c|c|c|c|}
\hline Non-Native Land Use & TP & TN & TSS & \\
\hline \multicolumn{5}{|l|}{ Urban } \\
\hline Urban & 0.80 & 5.00 & 2000.00 & USEPA 1976 \\
\hline Urban & 1.10 & 5.50 & & Reckhow et al. 1980 \\
\hline Mostly Urban & 0.03 & 0.79 & & USEPA 2002 \\
\hline Urban, developed & $0.45-1.50$ & $5.00-9.72$ & & Dodd et al. 1992, North Carolina \\
\hline Urban, residential & $0.60-1.90$ & & & Oberts et al. 1989, Minnesota \\
\hline Urban, residential & 0.25 & 0.35 & & MDEP 2000 \\
\hline Urban, residential & 1.49 & 6.15 & 208.60 & Reckhow et al. 1980, Philadelphia \\
\hline Urban, residential - Low densi & 1.25 & & & Cammermeyer et al 2000, L.Washington/Sammamish Watershed \\
\hline Urban, residential - High dens & 1.45 & & & Cammermeyer et al 2000, L. Washington/Sammamish Watershed \\
\hline Urban, high density, commercl & $1.70-3.00$ & & & Oberts et al. 1989, Minnesota \\
\hline Urban, commercial & 2.25 & & & Cammermeyer et al 2000, L.Washington/Sammamish Watershed \\
\hline Urban - Average & 1.80 & & & Cammermeyer et al 2000, L.Washington/Sammamish Watershed \\
\hline Lawns/Golf courses & 0.19 & 1.52 & & Reckhow et al. 1980 , Philadelphia \\
\hline Logging Roads & 3.50 & & & MDEP 2000 \\
\hline Public Highways & 3.50 & & & MDEP 2000 \\
\hline Camp and Private Roads & 3.50 & & & MDEP 2000 \\
\hline Municipal Waste Treatment PI & 7.70 & & & White \& Bayley 2001, Frank Lake AB \\
\hline Stormwater & 0.22 & \multicolumn{2}{|l|}{$10.3 \mathrm{NO} 3-\mathrm{N}$} & Dixon $1974^{\star}$, Calgary \\
\hline Stormwater & 1.00 & 5.00 & & Vokey 1998, Nova Scotia \\
\hline Stormwater & $0.26-2.50$ & $1.30-13.00$ & & Stanley Assoc. Eng. Ltd*, Fraser River Basin, BC \\
\hline Stormwater & 0.70 & & & Singer $1977^{*}$, Windsor ON \\
\hline Stormwater & 2.60 & & & Singer $1977^{\star}$, North York ON \\
\hline Stormwater - Residential & 1.30 & & & Marsalek $1984^{*}$ Burlington ON \\
\hline Stormwater-Commercial & 1.60 & & & Marsalek $1984^{\star}$ Burlington, ON \\
\hline Rain and runoff & \multicolumn{3}{|c|}{$0.71 \mathrm{NO} 3-\mathrm{N}$} & Ro et al. $1998^{*}$, Esther, AB \\
\hline Rain and runoff & 0.20 & & & Shaw et al. $1989^{*}$, Central Alberta \\
\hline \multicolumn{5}{|l|}{ Industrial } \\
\hline Industrial & 7.95 & 2.25 & 868.70 & Reckhow et al. 1980 \\
\hline Cargill Slaughter house & 50.00 & & & White \& Bayley 2001, Frank Lake AB \\
\hline Strip mines/barren land & 1.50 & 8.60 & & The Cadmus Group 1998, Schuylkill River Basin \\
\hline \multicolumn{2}{|l|}{ * Cited by Chambers et al. 2002} & & & \\
\hline \multicolumn{2}{|c|}{ "* Maine Dept.Env.Protection (MDEP) 2000} & & & \\
\hline
\end{tabular}




\subsubsection{Industrial Discharges}

Larger industries such as pulp and paper mills, mining operations manage their own waste independently unlike smaller lighter industries that discharge their wastes into nearby Municipal Waste Treatment Plants (MWTP). Mining operations, agricultural industries, and electrical power generation are other industrial point sources of phosphorus pollution in Alberta, but contribute less to the phosphorus load of rivers and lakes (Riemersma et al. 2002). The role of pulp and paper industries in river eutrophication is only now being recognized (Chambers et al. 2002)

Nutrient studies in Alberta have generally tended to examine the combined contributions of municipal wastes and industrial discharges in the form of basin studies. These include studies on the Northern River Basin (Chambers 1996) and Frank Lake (White and Bayley 2001). Data currently being gathered by the Oldman River Basin Water Quality Initiative will enable the calculation of export coefficients for selected subbasins (Saffran, pers.comm).

\subsubsection{OTHER CONSIDERATIONS}

\section{Wetlands and Riparian Areas}

In the case of river and freshwater wetlands, less information is available about their nutrient status, and available information is not presented as export coefficients. There is suggestive evidence that these systems may be nitrogen or phosphorus -limited when less affected by human activity (Morris 1991, Scrimgeour \& Chambers 2000). Wetlands are unique ecosystems that are characterized based on the areas they inhabit, vegetation, morphology, hydrology and chemistry. Riparian wetlands receive only seasonal flooding and records of export coefficients for these areas were not encountered in the review. These areas merit investigations into the dynamics of their nutrient and sediment loadings. 


\section{Recommendations and Conclusion}

\subsection{Recommendations}

It must be emphasized that that export coefficients are momentary values. They are based on hydrological and precipitation regimes, soil characteristics, land use and management practices, and may vary for even the same drainage basin from year to year. As such, they serve as estimates and are a useful scientific tool for comparative analyses. . Because $T$ (time) of experimental sampling for the determination of export coefficients can be variable, data may be extrapolated to generate the export coefficient in units of $\mathrm{kg} / \mathrm{ha} / \mathrm{yr}$.

Selection of coefficients are best done when the sample base (in this case, the number of records for a given cover type) is high. Statistical bias and errors will be minimal when the sample size is large (Zar, 1998). This is difficult for this exercise because of the paucity of information for the southern Alberta region. Other techniques need therefore be adopted.

It is recommended that the final selection of export coefficients for use in the ALCES model be made following a deliberation of information presented in this review by a panel consisting of members with knowledge of the southern Alberta region, the ALCES model, and the literature. For each land cover type or use, focus should be given to climate, soil types, topography, and location from where the export coefficient was recorded, spread of the data, and any other variables that could affect the selection of a value.

\subsection{Conclusion}

Currently, environmental problems caused by excessive nutrients are less severe in Canada than in countries with a longer history of settlement and agricultural production. This is because of the relatively small population of the country compared to its land base, coupled with the protective measures implemented by the federal, provincial and territorial governments over the last 30 years (Chambers et al. 2002). There are knowledge gaps for nutrients for export coefficients for various cover types and land uses in the southern Alberta region. This is an area where more studies need to be conducted. Increased knowledge will enable the development and adoption of management practices and technologies that will make the agricultural production and processing industry more environmentally sustainable. 


\section{References}

Anderson, A.M., Trew. D.O., McAlpine, N.D. \& Borg, R. 1998a. Impacts of agriculture on surface water quality in Alberta. Part 1: Haynes Creek Study. Alberta Agriculture, Food \& Rural Development, Edmonton, AB, Canada 83pp.

Anderson, A.M., Trew.D.O., McAlpine,N.D. \& Borg, R. 1998b. Impacts of agriculture on surface water quality in Alberta. Part 11 Provincial Stream Survey. : Haynes Creek Study. Alberta Agriculture, Food, Rural Development, Edmonton, AB, Canada 91pp.

Anderson, A.M., Saffran, K.A., Byrtus, G.\& Trew, D.O. 1998c. Impacts of agriculture on surface water quality in Alberta 111: Pesticides in small streams and lakes. Alberta Agriculture, Food \& Rural Development, Edmonton, AB, Canada 52pp

Barker, K.W., D.L. Sorensen, J.C. Andersen, J.M. Ihnat. 1989. Bear River Water Quality: Bioavailable Phosphorus Measurement, sources and control. UWRL, USU, Logan, Utah.

Beaulac, M.N. \& Reckhow, K.H. 1982. An examination of land use-nutrient export relationships. Water Resources Bulletin. 18(6): 1013-1024

Bondelid, T., Murray, B., Pattanayak, S., Lawrence, D., Yang, Jui-Chen., McCail, B. \& Gilling, D. 2001. Water Benefits and Co-Benefits of Greenhouse Gas Reduction Incentives in Agriculture and Forestry. EPA Contract No. 68-01-001

Boyd, L.E., Peterson, D.L., Running, S.W., Coughlan, J., Lamers, R., Dungan, J. \& Nemani, R. 1991. Forest ecosystem processes at the watershed scale: basis for distributed simulation. Ecological Modeling 56: 171-196

Cammermeyer, J., Conrecode, P., Hansen, J., Kwan, P. \& Maupin, M. 2000. P-Flux Determination: Juanita Creek analysis. http://courses.washington.edu/cewa/599c/paper2.html

Chambers, P.A \& Dale, A.R.1997. Contribution of industrial, municipal, agricultural and groundwater sources to nutrient export, Athabasca, Wapiti and Smoke Rivers. 1980-1993. Northern River Basins Study, Edmonton, AB.

Chambers, P.A., Dupont, J., Schaefer, K.A. \& Biaelek, A.T.2002 Effects of Agricultural Activities on Water Quality. Canadian Council of Ministers of the Environment. Winnipeg, Manitoba. CCME Linking Water Science to Policy Workshop Series Report No. 1

Cooke.S.E. \& Prepas, F.F. 1998. Stream phosphorus and nitrogen export from agricultural and forested watersheds in the Boreal Plain. Canadian Journal of Fisheries \& Aquatic Science. 55:2292-2299

Costanza, R. \& Maxwell, T.1991. Spatial ecosystem modeling using parallel processors. Ecological Modeling. 58: 159-183 
Costanza, R., Sklar, F.H. \& White, M.L.1990. Modeling coastal landscape dynamics. BioScience. 40: $91-107$

Dixon, R.W.J. 1974. Stormwater Quality and Loading in the Glenmore Reservoir. Engineering \& Environmental Service Department. The City of Calgary, AB

Devito, K.J., Fitzgerald, D., Hill, A.R. \& Aravena, R. 2000. Nitrate dynamics in relation to lithology and hydrogeologic flow path in a river riparian zone. Journal of Environmental Quality. 29: 10751084

Dodd, R.C., McMahon, G. \& Stichter, S. 1992. Watershed planning in the Albemarlo-Pamlico Estuaries System, Report 1 - Annual Average Nutrient Budgets. Report No. 92-10. AlbermarlePamlico Study, NC. Dept. of Environment, Health \& Natural Resources, Raleigh, NC.

Dormaar, J.F., Willms. W.D. 1993. Decomposition of blue grama and rough fescue roots in prairie soils. J. Range Manage. 46:207-213.

Dormaar, J.F., Willms. W.D. 1998. Effect of Forty-four years of grazing on fescue grassland soils. J. Range Manage. 46:207-213.

Douglas St.Onge., Kalf, J., Carnigan, P. \& Peters, R.H. 1999. The Forest is more than the trees: The effect of clear cutting on whole lake hypolimnetic oxygen deficits in remote Canadian Shield Lakes. Paper for Canadian Journal of Fisheries \& Aquatic Science.

http://www.openface.ca/ pete/paperl.pdf

Elkholm, P., 1994. Bioavailability of Phosphorous in Agriculturally Loaded Covers in Southern Farmland. Hydrobiologia 287: 179:194.

Ellis, B.K., Craft, J.A \& Stanford. 2000. Monitoring water quality in Flathead Lake, Montana: 2000 Progress Report. Open File Report 158-00. Flathead Lake Biological Stn. The University of Montana, Polson, MT 30pp.

Environment Canada. 1990. Off-farm sediment impacts in the Saskatchewan River Basin. M.A.Carson Associates, Victoria B.C. Canada. 87pp.

Fairchild, G.L., Barry, D.A.J., Gess, M.J., Hamill, A.S., Lafrance, P., Millburn, P.H., Simard, R.R., \& Zebarth, B.J., 2000. Groundwater Quality. In: Coote, D.R. \& Gregorich, L.J., (eds.), The Health of Our Water: Toward Sustainable Agriculture in Canada. 61-73. Research Branch of Agriculture and Agri-Food Canada, Publication 2020/E.

Green, D.J. 1996. Surface water quality impacts following winter application of hog manure in the Intelake Region, Manitoba Environment, Winnipeg, MB, Canada. Water Quality Management Report No. 96-14. 104pp.

Hargrave, A. \& Shaykewich, C.F. 1991. Nitrogen and Phosphorous Losses in Runoff Sediment due to Rainfall in Manitoba pp 266-241. Proceedings 1976 Manitoba Soil Science Workshop.

Howard, E.A., Olson, B.M. \& Cooke, S. 1999. Impact of Soil P Loading on Water Quality in Alberta: A Review. Alberta, Agriculture, Food and Rural Development, Edmonton. Alberta. 44pp. 
Jensen, M.B., Jorgensen, P.R., Hansen, H.C.B \& Nielsen, N.E. 1998. Biopore mediated subsurface transport of dissolved orthophosphate. Journal of Environmental Quality. 55: 11301138.

Larney, F.J., Izaurraido, R.C., Janzan, H.H., Olsen, B.M., Solberg, E.D., Lindwal, C.W. \& Nybing, M. 1995a. Soil Erosion - Crop productivity relationships for six Alberta soils. J. Soil \& Water Cons. $5087-91$.

Larney, F.J., Bullock, M.S., McCinn, S.M., Fryrean, D.W. 1995b. Quantifying Wind Erosion on summer fallow in Southern Alberta. J. Soil \& Water Cons. 50(1) 9195.

Lassevils, J.F. \& Berrux, D. 2000. Sources of phosphorus to surface waters: comparing calculated with measured P loadings for three French rivers, Geoplus Study for Centre Europeen d'Etudes des Polyphosphates. 68pp

Maine Department of Environmental Protection (MDEP). 2000. Madawaska Lake Total Maximum Daily (Annual) Load : Total Phosphorus: Final Lakes TMDL Report. DEPLW 2000-112

Manitoba Livestock Manure Management Initiative (MLMMI) 2002. Study of Regional Nutrient Balances in Four Municipalities in Manitoba 245p. http://www.mb.ca/projects/completed

Martin, C.W., Hornbeck, J.W., Likens, G.E. \& Buso, D.C. 2000. Impacts of intensive harvesting on hydrology and nutrient dynamics of northern hardwood forests. Canadian Journal of Fisheries \& Aquatic Science. 57(2): 19-29

McFarland, A.M.S. \& Hauek, L.M. 2001. Determining nutrient export coefficients \& source loading uncertainty using in-stream monitoring data. Joumal of the Amer. Water Res. Assoc. 37: 223-236.

Mitchell, P. \& Hamilton, H.R. 1982. Assessment of phosphorus export from the Majeau Creek watershed Lac la Nonne. Water Quality Control Branch, Alberta Environment. Edmonton, AB. Canada

Mitchell \& Trew, D.O. 1982. Agricultural Runoff and Lake Water Quality IN Agricultural Impacts on Surface and Groundwater Quality. Lethbridge. Sep 16-17, 1992. pp. 73-79.

Montana Dept. of Environmental Quality (MDEQ) 2001. Draft Nutrient Management Plan and Total Maximum Daily Load for Flathead Lake, Montana.

Morris, J.T. 1991. Effects of nitrogen loading on wetland ecosystems with particular reference to atmospheric deposition. Ann. Rev. Ecol. Syst. 22: 257-279.

Morrison, I.K. and N.W. Foster 1977. Fate of urea fertilizer added to a boreal forest Pinus banksiana Lamb. Soil Sci. Soc. Amer. J. 41: 441-448.

Nicholaichuk, W. \& Read, D.W. 1978. Nutrient Runoff from fertilized and unfertilized Fields. Western Can Journal of Environmental Quality. 7(4): 542-544.

Novotny, V. \& Chesters, G. 1981. Handbook of Non-point Pollution: Sources and Prevention. Van Nostrand Reinhold Company, New York, N.Y. 555pp.

Novotny, V. \& Chesters, G. 1989. Delivery of sediment and pollutants from Non-point sources: a water quality perspective. Journal of Soil and water Conservation. 44:568-576 
Oberts, G.L., Wotzka, P.J. \& Hartsoe, J.A. 1989. The water quality performance of select urban runoff treatment systems. Rept. to Legis. Comm. Minnesota Resources Metropolitan Council Pub. No. 590-89-062a. St. Paul MN.

Olness, A., Smith, S.J., Rhoades, E.D. \& Menzel, R.G. 1975. Nutrient and sediment discharge from agricultural watersheds in Oaklahoma. Journal of.Environmental Quality 4:331-336.

Ontkean, G.R., Bennet, D.R., Chanasysk, D.S. \& Sosiak, A. 2000. Impacts of Agriculture on Surface Water Quality in the Crowfoot Creek Watershed. Alberta Agriculture Research Institute. Project \# 97M062. 234pp.

Oosterveld, M. \& McMullin, R.W. 1979. Inflow - outflows of nutrients and sediments for a floodand sprinkler- irrigated watershed in Alberta. Canadian Journal of Soil Science. 59: 177-182.

Park, R.A., Collins, C.D., Leung, D.K., Boylen, C.W., Albanese, J., de Caprariis, P. \& Forstner, H. 1979. The aquatic ecosystem model MS.CLEANER In. S.E. Jorgensen (Editors). State-of-the-art in ecological modeling. International Society of Ecological Modeling, Copenhagen pp 579-602

Parton, W.J., Schirnel, D.S., Cole, C.V. \& Orirna, D.S. 1987. Analysis of factors controlling soil organic matter levels in Great Plains grasslands. Soil Science Society of America - Journal. 51: 1173-1179

Parton, W.J., Cole, C.V, \& Stewart, J.W.B. 1988. Dynamics of C, N, P, and S, in grassland soils: a model. Biogeochemistry 5:109-131

Pennock, D.J \& de Jong, E. 1987. The Influence of Slope Curvature on Soil Erosion \& Deposition in Hummocky Terrain. Soil Science 144(3): 209-217.

Pennock, D.J \& de Jong, E. 1990. Rates of Soil Redistribution associated with soil zones \& slope classes in S. Saskatchewan. Canadian Journal of Soil Science. 70: 325-334.

Prairie Farm Rehabilitation Administration (PFRA) 2000. Prairie Agricultural Landscapes: A Land Resource Review http://www.agr.gc.ca/pfra/pub/pallande.pdf

Reckhow, K.H., Beaulac, M.N \& Simpson (1980). Modeling Phosphorous loading and lake response under uncertainty: A manual \& compilation of export coefficients EPA 440/5-80-011 U.S.E.P.A $214 p p$

Riemersma, S., Little, J., Ontkean, G. \& Moskal-Herbert, T. 2002. Phosphorus Sources and Sinks in Water sheds: A Review. Irrigation Branch, Alberta Agriculture, Food \& Rural Development, Lethbridge, Alberta. 86pp.

Saunders, D.L. \& Kalff, J. 2001. Nitrogen Retention in wetlands, lakes and rivers. Hydrobiologia. 443 (1-3): 205-212.

Schuylkill River Watershed Conservation Plan 2001. Draft Report. A Manual \& Compilation of Export Coefficients Controlling Urban Runoff. http://www.schuylkillplan.org/pdfs

Scrimgeour, G.J. and P.A. Chambers. 2000 Cumulative effects of pulp mill and municipal effluents on epilithic biomass and nutrient limitation in a large northern river ecosystem. Canadian Journal of Fisheries and Aquatic Science. 57: 1342-1354. 
Sharpley, A.N., 1993. Assessing Phosphorous Bioavailability in Agricultural Soils and Runoff. Fertilizer Research 36: 259-272.

Sharpley, A.N., Daniel, T.C., Sims, J.T. \& Pote, D.H.1996. Determining Environmentally Sound Soil Phosphorous Levels. Journal of Soil \& Water Conservation 51: 160-166.

Silva, E.I.L \& Davis, R.W (1997). The effects of irrigation effluent on a Western Canadian Prairie River. Hydrobiologia 344: 103-109.

Sosiak, A.\& Trew, D.O. 1996. Pine Lake restoration project :Diagnostic Study (1992). Surface Water Assessment Branch, Alberta Environmental Protection. Edmonton, AB. 120pp.

Sosiak, A. 2000. Water Quality Sampling of the Little Bow River and Mosquito Creek in 1999. Alberta Environment, Water Section, Water management Division. 87pp.

Stauffer, J.C., Goldstein, R.M. \& Newman, R.M. 2000. Relationship of Wooded riparian zones and runoff potential to fish community composition in agricultural streams. Journal of Fisheries \& Aquatic Science 57 (2): 307-316.

Switzer-Howse, K.D. \& Coote, D.R. 1984. Agricultural practices and environmental conservation. Agriculture Canada. Ottawa, Ontario. LRRI. Contribution.

http://www.agr.gc.ca/cal/epub/1772e/1772_cover_e.html

The Cadmus Group. 1998. Watershed Assessment: Reading, Pennsylvania. Prepared for U.S. Environmental Protection Agency. Contract No. 68-C5-0061

Timmons, D.R. \& Holt, R.F. 1977. Nutrient Losses in surface runoff from a native prairie. Journal of Environmental Quality. 6: 369-373.

Timmons, D.R., Verry, E.S., Burwell, R.E. \& Holt, R.F. 1977. Nutrient transport in surface water runoff from an aspen-birch forest. Journal of Environmental Quality. 6:188-192

USEPA 1976. Areawide Assessment Procedures. Vols 1-111. Municipal Environmental Research Laboratory. Cincinnati, Ohio. EPA-600/9-76-014.

USEPA 2001. Methods for Evaluating Wetland Condition: Land-use characterization for Nutrient and Sediment Risk Assessment. Office of Water, U.S. Environmental Protection Agency, Washington. D.C. EPA-822-R-02-025.

USEPA 2002. Polluted Runoff (Nonpoint Source Pollution). National Management Measures to Control Nonpoint Source Pollution from Agriculture 314pp. http://www.epa.gov/owow/nps/agmm

van Vliet, L.J.P \& Hall, J.W. 1991. Effects of two crop rotations on seasonal runoff \& soil loss in the Peace River region. Can. J. Soil Sc. 71: 533-544.

Vitousek, P.M. and R.W. Howarth. 1991. Nitrogen limitation on land and in the sea: how can it occur? Biogeochem. 13: 87-115.

Vokey, J. 1998. Development of Unit Urban P Export Coefficients in the local watersheds of two mesotrophic lakes in Halifax Regional Municipality, NS Canada. Project - C (2. Lakes: Settle and Bissett). Soil and Water Conservation Society of Metro Halifax. 51pp. 
Weetman, G.F., Krause, H.H., Koller, E.\& Veilleux, J.M. 1987. Inter-provincial forest fertilization trials: 5- and 10-year results. Forest. Chron. 63: 184-192.

Wetzel, R. G. 2001. Limnology. Third Edn. Pub. Academic Press. 1006pp.

Wilhelm, F.M. \& Schindler, D.W. (1999). Effects of Gammarus lacustris (Crustacea: Amphipoda) on plankton community structure in an Alpine Lake. Canadian Journal of Fisheries and Aquatic Sciences 56(8): $1401-1408$.

White, J.S. \& Bayley, S.E. 2001. Nutrient retention in a northern prairie marsh (Frank Lake, Alberta) receiving municipal and agro-industrial wastewater. Air, Water and Soil Pollution. 126: 6381

Zar, J.H 1998. Biostatistical Analysis. Fourth Edn. Pub. Pearson Education. 663pp

Xue, Y., David, M.B., Gentry, L.E. \& Kovacic, D.A.1998. Kinetics and modeling of dissolved phosphorous export from a tile -drained agricultural watershed. Journal of Environmental Quality. 27(4): 917-922 


LIBRARY AND ARCHIVES CANADA

Bibliothèque et Archives Canada

33286538600798 